\title{
KARAKTERISTIK KANDUNGAN LEMAK DAN ASAM LEMAK COKELAT BATANG YANG TERBUAT DARI OLEOGEL MINYAK NABATI DAN COCOA BUTTER SUBSTITUTE (CBS) KOMERSIL DENGAN OLEOGATOR LEMAK KAKAO
}

\author{
Characteristic of Fat Content and Fatty Acid Composition of Chocolate Compound \\ Made from Vegetable Oil Oleogel and Cocoa Butter Substitute with Cocoa Butter \\ Oleogator
}

\author{
Dyah Wuri Asriati, Wahyuni, St. Ramlah, Andi Nur Amalia, dan Eky Yenita Ristanti \\ Balai Besar Industri Hasil Perkebunan \\ Jln. Prof. Dr. H. Abdurahman Basalamah No. 28 Makassar \\ e-mail : dyahw_asriati@yahoo.com
}

\begin{abstract}
This study aims to determine the characteristics of the composition of fatty acids and the constituent ingredients of chocolate bar products made from vegetable oil oleogels and commercial Cocoa Butter Substitute with cocoa butter oleogators. Chocolate compound are made with 10 formulas namely $F_{1}-F_{10}$, where $F_{1}-F_{8}$ uses oleogel from palm oil or soybean oil instead of cocoa butter, while $F_{9}-F_{10}$ uses commercial Cocoa Butter Substitute (CBS). The formula for making oleogel includes $90 \%$ palm oil or soybean oil, $7 \%$ and $9 \%$ beeswax and $1 \%$ and $3 \%$ cocoa butter. Fatty acid analysis was performed using the gas chromatography method. The results showed that the highest fat content was obtained in the chocolate paste formula with palm oil oleogel with value of $43.31 \%$, while the lowest was obtained in the cocoa powder formula from the palm oil oleogel with value of $28.80 \%$. While the highest total fatty acid content is found in the formula for chocolate paste and soybean oil oleogel with levels of $93.12 \%$, while the lowest values in the formula for cocoa powder and soybean oil oleogel with levels of $83.77 \%$.
\end{abstract}

Keywords: oleogel, fatty acids, fat content, chocolate bars, gas chromatography

Abstrak: Penelitian ini bertujuan untuk mengetahui karakteristik komposisi asam lemak dan bahan penyusun produk cokelat batang yang terbuat dari oleogel minyak nabati dan Cocoa Butter Substitute komersil dengan oleogator lemak kakao. Pembuatan cokelat batang dibuat dengan 10 formula yaitu $F_{1}-F_{10}$, dimana $F_{1}-F_{8}$ menggunakan oleogel dari minyak sawit atau minyak kedelai sebagai pengganti lemak kakao, sedangkan $F_{9}-F_{10}$ menggunakan Cocoa Butter Substitute (CBS) komersil. Formula pembuatan oleogel meliputi $90 \%$ minyak sawit atau minyak kedelai, 7\% dan 9\% beeswax serta 1\% dan 3\% lemak kakao. Analisis asam lemak dilakukan dengan menggunakan metode gas kromatografi. Hasil penelitian menunjukkan bahwa kandungan lemak yang paling tinggi didapat pada formula pasta kakao dengan oleogel minyak sawit dengan nilai $43,31 \%$, sedangkan yang terendah didapat pada formula bubuk kakao dari oleogel minyak sawit dengan nilai $28,80 \%$. Kandungan asam lemak total tertinggi terdapat pada formula pasta kakao dan oleogel minyak kedelai dengan kadar 93,12\%, sedangkan nilai terendah pada formula bubuk kakao dan oleogel minyak kedelai dengan kadar 83,77\%.

Kata Kunci: oleogel, asam lemak, kandungan lemak, cokelat batang, kromatografi gas

\section{PENDAHULUAN}

Cokelat didefinisikan sebagai produk homogen yang dihasilkan melalui proses pencampuran produk kakao dengan atau tanpa penambahan susu, gula dan atau bahan pemanis lainnya, dan atau bahan tambahan pangan (CAC, 2003). Produk hasil olahan kakao memiliki sifat yang spesial dari pangan lainnya, bukanlah karena rasa dan nutrisinya yang baik, tetapi karena sifatnya yang tidak dimiliki oleh pangan yang lain yaitu bersifat padat di suhu ruang, rapuh saat dipatahkan dan meleleh sempurna pada suhu tubuh. Produk olahan sekunder yang paling 
mudah diperoleh yaitu cokelat batang (Lipp dan Anklam, 1998).

Bahan baku pembuatan cokelat batang adalah bubuk kakao atau pasta kakao, lemak kakao, susu full cream, gula, lesitin, garam dan vanili yang kemudian diconching selama 4 jam. Komposisi bahan dalam pembuatan cokelat sangat beragam, setiap industri cokelat memiliki perbandingan bahan yang berbeda. Setiap perbandingan menghasilkan cita rasa, warna dan tekstur yang berbeda. Pada umumnya, ada 3 jenis cokelat yaitu cokelat pekat (dark chocolate), cokelat susu (milk chocolate), dan cokelat putih (white chocolate). Ketiga macam cokelat ini dibedakan berdasarkan komposisinya, yaitu kandungan cokelat, gula, serta bahan tambahan lain (Brown, 2010). Milk Chocolate dibuat dari pasta kakao, lemak kakao, gula dan susu full cream yang dikombinasikan dalam berbagai proporsi. Dark chocolate menggunakan proses yang sama milk chocolate akan tetapi tanpa penggunaan susu full cream sedangkan white chocolate dibuat dengan lemak kakao, susu full cream dan gula tanpa pasta atau bubuk kakao (Aini, 2011). Cokelat putih (white chocolate) memiliki komposisi yang hampir sama dengan milk chocolate namun tidak mengandung cokelat padat melainkan menggunakan lemak cokelat (cocoa butter) (Brown, 2010). Cokelat ini biasanya dijual agar bisa menghasilkan berbagai macam warna untuk permen cokelat ataupun kue (Atkinson et al.,

2010). White chocolate setidaknya mengandung 20\% lemak kakao, 14\% susu full cream, 3,5\% lemak susu ( $\mathrm{krim}$ ), sekitar maksimal $55 \%$ gula dan bahanbahan lainnya (U.S. FDA, 2015). Secara teknis, cokelat putih tidak dapat dikategorikan sebagai cokelat karena tidak mengandung kakao padat (Brown, 2010).

Lemak kakao merupakan jenis lemak yang paling sesuai untuk makanan cokelat. Lemak kakao berupa lemak padat dengan titik leleh $32-35{ }^{\circ} \mathrm{C}$ berwarna kuning terang yang diperoleh dari biji kakao. Lemak kakao bersifat keras dan rapuh dibawah suhu ruang, tetapi ketika dimakan akan meleleh sempurna di mulut dengan tekstur yang lembut. Oleh karena itu dalam industri yang terutama produk-produk cokelat, lemak kakao merupakan bahan baku yang berkontribusi penting terhadap sifat tekstural dan sensori produk (Sokopitojo, 2008). Akan tetapi, ada keterbatasan dalam memproduksi lemak kakao antara lain adalah suplai biji kakao yang tidak menentu, kualitas biji kakao yang kurang memadai dalam pengolahan lemak kakao serta harga yang relatif mahal. Oleh karena itu, berbagai upaya dilakukan untuk mengembangkan spesialti fats sebagai alternatif penggunaan lemak kakao, salah satunya adalah penggunaan Cocoa Butter Substitute (CBS).

Cocoa Butter Substitute (CBS) merupakan salah satu lemak pengganti lemak kakao, walaupun memiliki karakteristik yang tidak kompatibel dengan lemak kakao akan tetapi memiliki keuntungan yakni harga yang lebih murah. Menurut Elisabeth et al., (2008), CBS lebih ditujukan pada produk lemak yang menggunakan minyak non laurat dari inti sawit. Penggunaan CBS dalam pembuatan produk cokelat dapat menghasilkan kualitas produk cokelat hampir sama dengan cokelat menggunakan lemak kakao. Menurut Heriyadi (2009) dalam Noordiansyah (2016), CBS dapat digunakan untuk pengganti lemak cokelat khususnya untuk produksi cokelat yang lebih murah. Pada dasarnya selain menekan harga, CBS juga mempunyai kelebihan antara lain mempunyai stabilitas oksidatif yang baik, sehingga memberikan masa simpan yang lebih lama, mempunyai tekstur yang sangat mirip dengan lemak kakao khususnya dalam hal kekerasan, memberikan mutu kilap (gloss quality) dan ketahanan kilap (gloss retention) yang baik, tersedia dalam harga yang jauh lebih murah daripada harga lemak kakao.

Dalam industri pangan,
pembuatan
cokelat menggunakan Cocoa Butter Substitute (CBS) berbasis sawit telah banyak 
dilakukan. Namun untuk menghasilkan produk cokelat batang berbasis lemak nabati yang lebih bernutrisi maka perlu dilakukan penambahan zat gizi seperti salah satu penelitian Ristanti, et al., (2017) mengenai oleogel dari minyak sawit dan minyak kedelai. Oleogel yang terbuat dari minyak sawit dan minyak kedelai mengandung asam-asam lemak yang bermanfaat bagi tubuh seperti asam palmitat, asam oleat, asam stearat, dan asam linoleat. Minyak sawit mempunyai komposisi asam lemak jenuh dengan proporsi yang seimbang. Berdasarkan komposisi asam lemak jenuh dan tak jenuh yang seimbang maka secara ideal bisa menjadi produk oleogel yang dapat diaplikasikan ke dalam produk makanan sehingga dapat menjadi salah satu alternatif untuk meningkatkan mutu produk cokelat batang dengan tekstur yang lebih baik (Hariyadi, 2014).

Oleogel didefinisikan sebagai lemak lipofilik dan campuran padat, dimana material lemak padat (oleogator) dengan konsentrasi yang lebih rendah $(<10 \%)$ dapat menjerap dengan cara membentuk jejaring oleogator pada minyak curah. Oleogator dapat digolongkan menjadi dua, yakni sistem self-assembly dan sistem partikel kristal (Samuditha et al., 2011). Oleogelasi atau proses pembentukan oleogel, meliputi gelasi dari minyak dengan bantuan gelator tunggal atau kombinasi sinergis dari beberapa molekul gelator yang berbeda (Patel dan Dewettinek, 2015). Oleogelasi menjadi solusi untuk menjawab tantangan kebutuhan teknologi untuk mengubah struktur minyak pangan yang ada.

Minyak dan lemak jenuh, memicu masalah kesehatan seperti kolesterol tinggi yang dapat memicu penyakit stroke dan jantung. Oleh karena itu, industri makanan mulai menaruh perhatian terhadap bahan-bahan yang dapat menggantikan peranan minyak dan lemak jenuh pada makanan olahan tanpa merusak tekstur dan sifat fisik yang diharapkan. Oleogelasi merupakan proses untuk menata struktur minyak dan lemak sehingga ketika diaplikasikan pada produk makanan olahan dapat memperbaiki karakteristik fungsional seperti tekstur, kerenyahan, tampilan dan stabilitas. Selain itu, proses ini juga tidak memerlukan biaya yang mahal dan tidak berdampak negatif terhadap kesehatan (Ristanti et al., 2018). Oleogel yang terbuat dari minyak sawit dan minyak kedelai mengandung asam-asam lemak yang bermanfaat bagi tubuh seperti asam palmitat, asam oleat, asam stearat, dan asam linoleat.

Tujuan dari penelitian ini adalah untuk mengetahui karakteristik komposisi asam lemak dan bahan penyusun pada produk cokelat batang yang terbuat dari oleogel minyak kedelai dan minyak sawit serta Cocoa Butter Substitute komersil dengan oleogator lemak kakao.

\section{METODOLOGI}

\section{Bahan dan Alat Penelitian}

Adapun bahan-bahan yang digunakan antara lain minyak kedelai merek Happy Soya, minyak kelapa sawit merek Tropical, beeswax, lemak kakao, CBS komersil, pasta kakao fermentasi, bubuk kakao fermentasi, gula, lesitin, vanili, garam, susu bubuk full cream.

Alat-alat yang digunakan antara lain penangas air, alat pengaduk Ultra Turrax merek IKA tipe T25, gelas plastik steril $150 \mathrm{ml}$, botol kaca vakum, tabung Eppendorf, alat sentrifugasi merek Hettick tipe EBA 200, conching (Universal Conching) merek United Kingdom, melter, meja getar dan cetakan cokelat.

\section{Waktu dan Tempat Penelitian}

Penelitian dilakukan pada bulan Maret-Mei 2018 di Laboratorium Rekayasa Produk Balai Besar Industri Hasil Perkebunan Makassar. Cakupan penelitian ini meliputi dari pembuatan oleogel dari minyak kelapa sawit dan minyak kedelai yang dilanjutkan ke pengaplikasian pembuatan cokelat batang yang menggunakan oleogel dari minyak sawit merek Tropical, minyak kedelai merek Happy Soya dan CBS komersil. 
Metode Penelitian Pembuatan Oleogel

Pada penelitian ini dibuat terlebih dahulu dengan menggunakan minyak sawit merek Tropical dan minyak kedelai merek Happy Soya, ditambahkan dengan beeswax dan lemak kakao. Dipersiapkan untuk volume 500 gram setiap perlakuan. Adapun formulasi untuk setiap perlakuan dapat dilihat pada Tabel 1.

Tabel 1. Formula Pembuatan Oleogel

\begin{tabular}{ccccccc}
\hline & & \multicolumn{5}{c}{ Butter Substitute } \\
\cline { 3 - 7 } No & Formula & CBS & $\begin{array}{c}\text { Minyak } \\
\text { Sawit }\end{array}$ & $\begin{array}{c}\text { Minyak } \\
\text { Kedelai }\end{array}$ & Beeswax & $\begin{array}{c}\text { Lemak } \\
\text { Kakao }\end{array}$ \\
\hline 1 & & 0 & $90 \%$ & 0 & $9 \%$ & $1 \%$ \\
2 & $\mathrm{~S}_{1}$ & 0 & $90 \%$ & 0 & $7 \%$ & $3 \%$ \\
3 & $\mathrm{~K}_{3}$ & 0 & 0 & $90 \%$ & $9 \%$ & $1 \%$ \\
4 & $\mathrm{~K}_{3}$ & 0 & 0 & $90 \%$ & $7 \%$ & $3 \%$
\end{tabular}

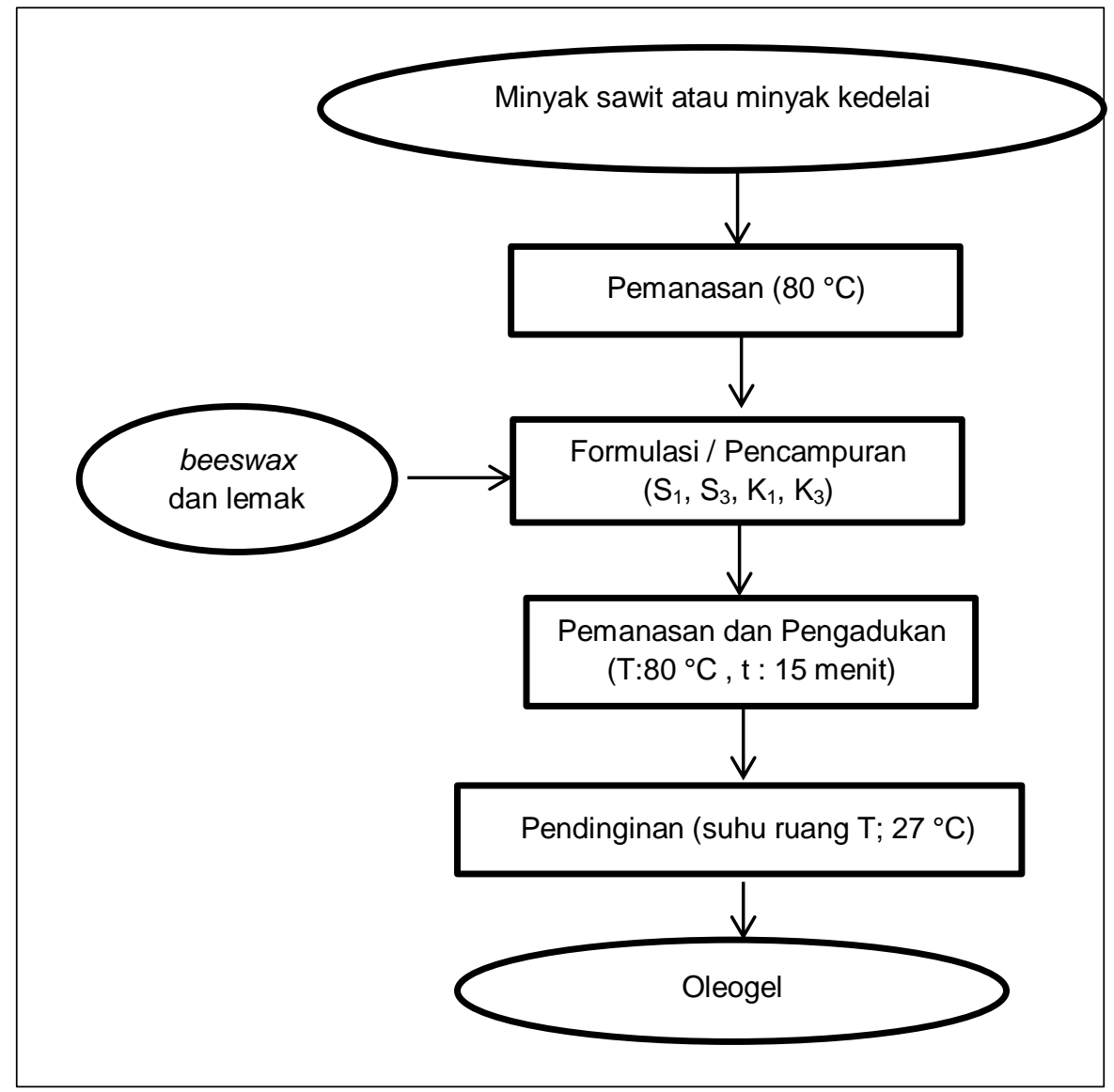

Gambar 1. Alur pembuatan oleogel

\section{Pembuatan Cokelat Batang}

Penelitian pembuatan cokelat batang menggunakan pendekatan kuantitatif dengan metode percobaan laboratorium mengacu pada penelitian pembuatan cokelat (Ramlah, 2016). Penelitian ini dilakukan sebanyak 10 formula yaitu $\mathrm{PS}_{1}$ (Pasta kakao, oleogel dari minyak sawit dan kadar beeswax
9\%), $\mathrm{PS}_{3}$ (Pasta kakao, oleogel dari minyak sawit dan kadar beeswax 7\%), $\mathrm{PK}_{1}$ (Pasta kakao, oleogel dari minyak kedelai dan kadar beeswax $9 \%$ ), $\mathrm{PK}_{3}$ (Pasta kakao, oleogel dari minyak kedelai dan kadar beeswax 7\%), BS $_{1}$ (Bubuk kakao, oleogel dari minyak sawit dan kadar beeswax 9\%), BS $_{3}$ (Bubuk kakao, oleogel dari minyak sawit dan 
kadar beeswax 7\%), BK 1 (Bubuk kakao, oleogel dari minyak kedelai dan kadar beeswax 9\%), $\mathrm{BK}_{3}$ (Bubuk kakao, oleogel dari minyak kedelai dan kadar beeswax 7\%), PCBS (Pasta kakao, CBS), BCBS (Bubuk kakao, CBS). Formula pembuatan cokelat batang, dapat dilihat pada Tabel 2.

Tabel 2. Formula Pembuatan Cokelat Batang

\begin{tabular}{ccccccccc}
\hline No & Formula & $\begin{array}{c}\text { Pasta } \\
(\mathrm{g})\end{array}$ & $\begin{array}{c}\text { Bubuk } \\
(\mathrm{g})\end{array}$ & $\begin{array}{c}\text { Susu } \\
(\mathrm{g})\end{array}$ & Gula $(\mathrm{g})$ & $\begin{array}{c}\text { Garam } \\
(\mathrm{g})\end{array}$ & $\begin{array}{c}\text { Lesitin } \\
(\mathrm{g})\end{array}$ & $\begin{array}{c}\text { Vanilli } \\
(\mathrm{g})\end{array}$ \\
\hline 1 & $\mathrm{PS}_{1}$ & 2000 & 0 & 2000 & 2000 & 4 & 30 & 8 \\
2 & $\mathrm{PS}_{3}$ & 2000 & 0 & 2000 & 2000 & 4 & 30 & 8 \\
3 & $\mathrm{PK}_{1}$ & 2000 & 0 & 2000 & 2000 & 4 & 30 & 8 \\
4 & $\mathrm{PK}_{3}$ & 2000 & 0 & 2000 & 2000 & 4 & 30 & 8 \\
5 & $\mathrm{BS}_{1}$ & 0 & 2000 & 2000 & 2000 & 4 & 30 & 8 \\
6 & $\mathrm{BS}_{3}$ & 0 & 2000 & 2000 & 2000 & 4 & 30 & 8 \\
7 & $\mathrm{BK}_{1}$ & 0 & 2000 & 2000 & 2000 & 4 & 30 & 8 \\
8 & $\mathrm{BK}_{3}$ & 0 & 2000 & 2000 & 2000 & 4 & 30 & 8 \\
9 & $\mathrm{PCBS}_{1}$ & 2000 & 0 & 2000 & 2000 & 4 & 30 & 8 \\
10 & BCBS & & 2000 & 2000 & 2000 & 4 & 30 & 8 \\
\hline
\end{tabular}

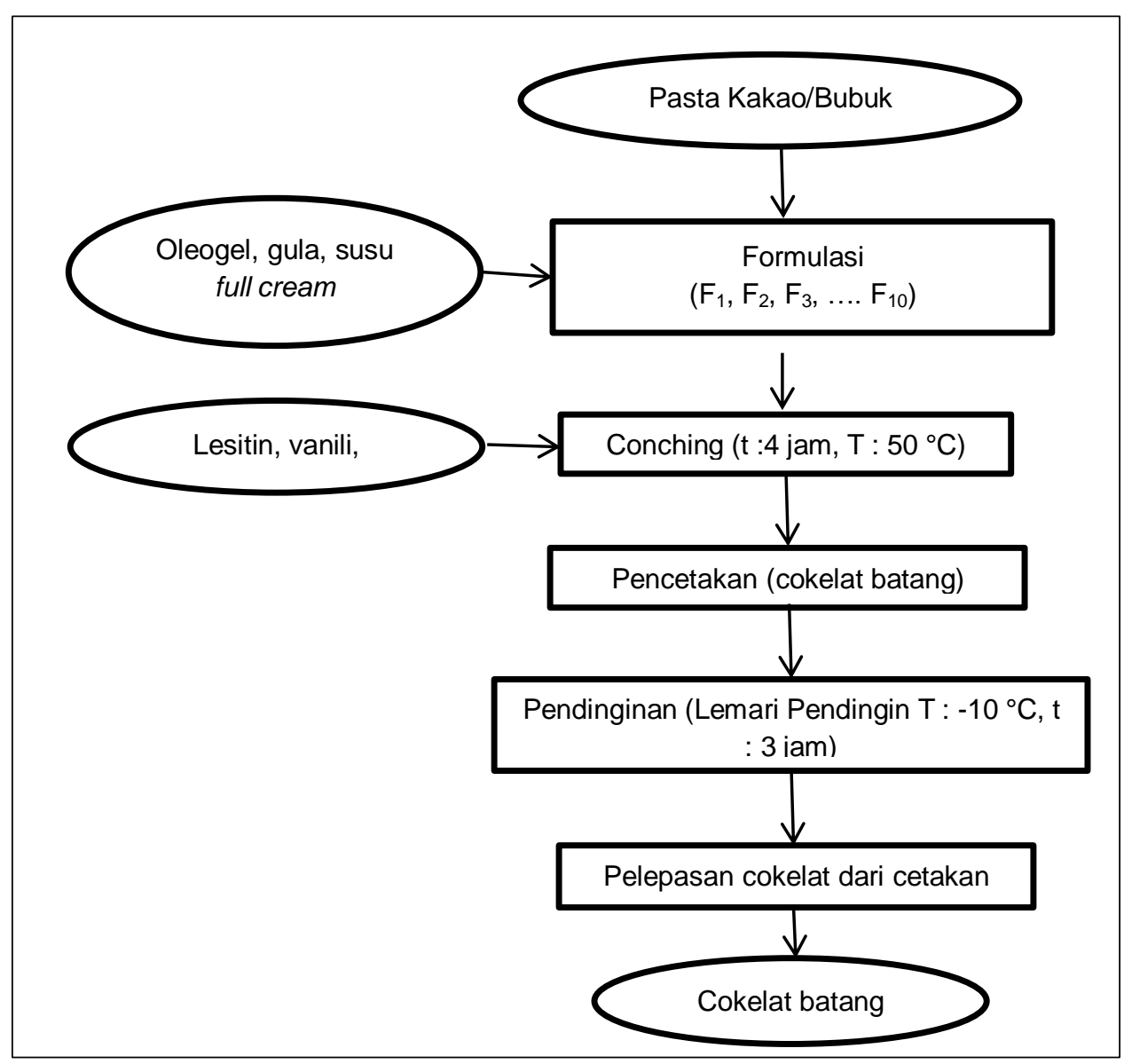

Gambar 2. Diagram Alir pembuatan cokelat batang 


\section{Pengujian Hasil Penelitian}

Parameter uji yang digunakan pada penelitian yaitu pengujian fatty acid dengan metode uji HPLC, fat content dengan metode uji soxhlet. Data hasil uji laboratorium diolah secara deskriptif. Pengertian analisis data secara deskriptif adalah teknik analisis yang digunakan dalam menganalisis data dengan membuat gambaran data-data yang terkumpul tanpa membuat generalisasi dari hasil penelitian tersebut.

\section{HASIL DAN PEMBAHASAN Kandungan Lemak}

Kadar lemak pada cokelat batang yang dihasilkan sangat dipengaruhi oleh kandungan lemak dari bahan baku yang digunakan seperti pasta kakao atau bubuk kakao, lemak kakao lemak lainnya, beeswax, susu full cream, dan lain-lain. Pada penelitian ini, kadar lemak pada cokelat batang yang dihasilkan dipengaruhi oleh bahan baku oleogel yang digunakan sebagai pengganti lemak kakao. Selain itu, juga dipengaruhi oleh bahan baku pasta kakao dan bubuk kakao. Namun, jika dibandingkan antara satu formula dengan formula lainnya, maka penggunaan oleogel tidak terlalu besar mempengaruhi kadar lemak cokelat yang dihasilkan karena setiap formula menggunakan volume atau jumlah oleogel yang sama. Namun, jika dilihat dari penggunaan bahan baku bubuk kakao dan pasta kakao, maka produk cokelat yang diolah dari bahan baku bubuk kakao mempunyai kadar lemak yang lebih rendah dibanding dengan cokelat yang diolah dari pasta kakao. Bubuk kakao mempunyai kadar lemak yang lebih rendah dari pasta kakao karena bubuk kakao merupakan produk yang dihasilkan dari proses pengepresan pasta kakao sehingga lemak kakao yang terdapat dalam pasta kakao terpisah atau keluar dari pasta dan diperoleh cake yang selanjutnya dijadikan bubuk kakao.

Hasil pengujian kandungan lemak pada penelitian ini dapat dilihat pada Tabel 3.

Tabel 3. Hasil Pengujian Kandungan Lemak pada 10 Formulasi Cokelat Batang

\begin{tabular}{lllllllllll}
\hline & $\begin{array}{l}\mathrm{PS}_{1} \\
\left(\mathrm{~F}_{1}\right)\end{array}$ & $\begin{array}{l}\mathrm{PS}_{3} \\
\left(\mathrm{~F}_{2}\right)\end{array}$ & $\begin{array}{l}\mathrm{PK}_{1} \\
\left(\mathrm{~F}_{3}\right)\end{array}$ & $\begin{array}{l}\mathrm{PK}_{3} \\
\left(\mathrm{~F}_{4}\right)\end{array}$ & $\begin{array}{l}\mathrm{BS}_{1} \\
\left(\mathrm{~F}_{5}\right)\end{array}$ & $\begin{array}{l}\mathrm{BS}_{3} \\
\left(\mathrm{~F}_{6}\right)\end{array}$ & $\begin{array}{l}\mathrm{BK}_{1} \\
\left(\mathrm{~F}_{7}\right)\end{array}$ & $\begin{array}{l}\mathrm{BK}_{3} \\
\left(\mathrm{~F}_{8}\right)\end{array}$ & $\begin{array}{l}\mathrm{PCBS} \\
\left(\mathrm{F}_{9}\right)\end{array}$ & $\begin{array}{l}\mathrm{BCBS} \\
\left(\mathrm{F}_{10}\right)\end{array}$ \\
\hline $\begin{array}{l}\text { Kandungan } \\
\text { Lemak (\%) }\end{array}$ & 32,33 & 43,31 & 34,95 & 35,0 & 28,80 & 32,72 & 31,73 & 35,41 & 40,14 & 33,94 \\
\hline
\end{tabular}

Penambahan beeswax juga dapat mempengaruhi jumlah kadar lemak. Hal ini dapat dilihat dari data pada Tabel 3 , yang mana formula dengan penambahan beeswax 9\% (PS $\left., \mathrm{PK}_{1}, \mathrm{BS}_{1}, \mathrm{BK}_{1}\right)$ mendapatkan hasil kandungan lemak lebih kecil dibandingkan dengan penambahan beeswax $7 \%\left(\mathrm{PS}_{3}, \mathrm{PK}_{3}\right.$, $\mathrm{BS}_{3}, \mathrm{BK}_{3}$ ).

Hasil analisa kandungan lemak (fat content) cokelat batang (Tabel 3) dengan penggunaan lemak oleogel $\left(F_{1}\right.$ s/d $\left.F_{8}\right)$ berkisar dari $28,80 \%$ hingga $43,31 \%$. Kadar lemak tertinggi diperoleh dari cokelat dengan formula pasta kakao dengan oleogel dari minyak kelapa sawit $\left(\mathrm{PS}_{3}\right)$ dan yang terendah pada formula bubuk kakao dengan oleogel minyak sawit $\left(B_{1}\right)$. Hal ini selaras dengan yang menggunakan CBS, hasil terendah kandungan lemak terdapat pada formula bubuk kakao dan yang tertinggi di formula pasta kakao.

\section{Asam Lemak}

Hasil penelitian menunjukkan bahwa asam lemak yang dominan adalah asam palmitat, asam oleat dan asam stearat. Lemak kakao merupakan lemak yang relatif sederhana, dimana komponen utama asam lemaknya (95\%) hanya tersusun dari asam palmitat, asam stearat dan asam oleat. Hasil pengujian asam lemak pada penelitian ini dapat dilihat pada Tabel 4. 
Jurnal Industri Hasil Perkebunan Vol. 15 No. 1, Juni 2020: 74-82

Tabel 4. Hasil Penelitian Parameter Asam Lemak pada 10 Formula Cokelat Batang

\begin{tabular}{|c|c|c|c|c|c|c|c|c|c|c|c|}
\hline \multicolumn{2}{|c|}{ Komponen Asam Lemak (\%) } & $\begin{array}{c}\mathrm{F} 1 \\
\left(\mathrm{PS}_{1}\right)\end{array}$ & $\begin{array}{c}\mathrm{F} 2 \\
\left(\mathrm{PS}_{3}\right)\end{array}$ & $\begin{array}{c}\mathrm{F} 3 \\
\left(\mathrm{PK}_{1}\right)\end{array}$ & $\begin{array}{c}\mathrm{F} 4 \\
\left(\mathrm{PK}_{3}\right)\end{array}$ & $\begin{array}{c}\mathrm{F} 5 \\
\left(\mathrm{BS}_{1}\right)\end{array}$ & $\begin{array}{c}\mathrm{F} 6 \\
\left(\mathrm{BS}_{3}\right)\end{array}$ & $\begin{array}{c}\mathrm{F} 7 \\
\left(\mathrm{BK}_{1}\right)\end{array}$ & $\begin{array}{c}\mathrm{F} 8 \\
\left(\mathrm{BK}_{3}\right)\end{array}$ & $\begin{array}{c}\text { F9 } \\
\text { (PCBS) }\end{array}$ & $\begin{array}{c}\text { F10 } \\
\text { (BCBS) }\end{array}$ \\
\hline & Asam Lemak Jenuh & & & & & & & & & & \\
\hline 1 & Asam Caprilic (C8:0) & 0,12 & 0,08 & 0,10 & 0,09 & 0,12 & 0.13 & 0,08 & 0,09 & 2,04 & 2,22 \\
\hline 2 & Asam Capric, (C10:0) & 0,23 & 0,17 & 0,20 & 0,19 & 0,25 & 0,24 & 0,19 & 0,20 & 1,94 & 2,33 \\
\hline 3 & Asam Laurid, (C12:0) & 0,46 & 0,36 & 0,34 & 0,34 & 0,49 & 0,50 & 0,36 & 0,39 & 28,08 & 35,46 \\
\hline 4 & Asam Myristic, (C14:0) & 1,57 & 1,25 & 1,04 & 1,04 & 1,76 & 1,71 & 1,10 & 1,09 & 9,45 & 11,74 \\
\hline 5 & Asam Palmitic, (C16:0) & 30,28 & 29,40 & 17,49 & 17,71 & 31,69 & 31,35 & 15,36 & 14,48 & 15,40 & 13,04 \\
\hline 6 & $\begin{array}{l}\text { Asam Stearic, (C18:0) } \\
\text { Asam Lemak Tidak Jenuh }\end{array}$ & 13,62 & 12,41 & 13,02 & 13,00 & 11,08 & 10,96 & 9.84 & 9,47 & 20,02 & 16,96 \\
\hline 1 & Asam Oleic, (C18:1n9c) & 33,07 & 33,52 & 24,10 & 24,34 & 35,03 & 34,51 & 21,58 & 20,44 & 12,17 & 8,67 \\
\hline 2 & Asam Linoleic (C18:2n6c) & 7,63 & 7,51 & 30,96 & 31,79 & 9,45 & 8,72 & 34,76 & 33,21 & 1,24 & 0,99 \\
\hline 3 & Asam Linoleni,c (C18:3n3) & 0,30 & 0,27 & 2,98 & 2,84 & 0,33 & 0,30 & 3,05 & 2,90 & 0,11 & 0,09 \\
\hline 4 & $\begin{array}{l}\text { Asam cis-11,14-Eicosedieno } \\
\text { (C20:2) }\end{array}$ & 0,04 & 0,04 & 0,04 & 0,04 & 0,04 & 0,04 & 0,03 & 0,02 & - & - \\
\hline 5 & $\begin{array}{l}\text { Asam cis-5,8,11,14,17- } \\
\text { Eicosapentaenoic C20:5n3 }\end{array}$ & - & 0,03 & - & - & - & - & - & - & - & - \\
\hline 6 & Asam Behenic (C22:0) & 0,09 & 0,09 & 0,20 & 0,23 & 0,09 & 0,08 & 0,20 & 0,20 & 0,06 & 0,04 \\
\hline 7 & Asam Tricosanoic (C23:0) & - & - & 0,02 & 0,03 & 0,02 & - & 0,02 & 0,02 & -- & - \\
\hline 8 & Asam Lignoceric (C24:0) & 0,08 & 0,07 & 0,11 & 0,11 & 0,08 & 0,08 & 0,10 & 0,10 & 0,05 & 0,04 \\
\hline 9 & $\begin{array}{l}\text { Asam cis- } 4,7,10,13,16,19- \\
\text { Docosahexaenoic } \\
\text { (C22:6n3) }\end{array}$ & - & 0,04 & - & - & 0,03 & - & - & - & - & - \\
\hline & Asam Lemak Total & 88,83 & 86,33 & 91,95 & 93,12 & 91,79 & 89,90 & 87,86 & 83,77 & 92,34 & 92,61 \\
\hline
\end{tabular}

Perbedaan kadar asam lemak dari tiap jenis asam lemak pada cokelat batang dipengaruhi oleh jenis minyak atau lemak pada oleogel yang digunakan dalam pembuatan cokelat batang. Menurut Sartika (2008), kandungan lemak dan komposisi asam lemak dalam kedelai dipengaruhi oleh varietas dan keadaan iklim tempat tumbuh. Lemak kasar terdiri dari trigliserida sebesar 90$95 \%$, sedangkan sisanya adalah fosfatida, asam lemak bebas, sterol, dan tokoferol. Minyak kedelai mempunyai kadar asam lemak jenuh. Lemak dan komposisi asam lemak dalam kedelai dipengaruhi oleh varietas dan keadaan iklim tempat tumbuh. Lemak kasar terdiri dari gliserida sebesar 90-95\%. Sedangkan sisanya adalah fosfatida, asam lemak bebas, sterol dan tokoferol sekitar $15 \%$ sehingga sangat baik sebagai pengganti lemak dan minyak yang memiliki kadar asam lemak jenuh yang tinggi seperti mentega dan lemak babi. Hal ini berarti minyak kedelai sama seperti minyak nabati lainnya yang bebas kolesterol. Asam lemak dalam minyak kedelai sebagian besar terdiri dari asam lemak esensial yang sangat dibutuhkan oleh tubuh. Komposisi kimia dan sifat fisiko kimia minyak kedelai yaitu mengandung asam lemak tidak jenuh $(85 \%)$ yang terdiri dari asam linoleat 15 $64 \%$, asam oleat $11-60 \%$, asam linolenat $1-12 \%$, asam arachidonat 1,5\%, sedangkan asam lemak jenuh (15\%) yang terdiri dari asam palmitat $7-10 \%$, asam stearat $2-5 \%$, asam arschidat 0,2$1 \%$, asam laurat 0-0,1\% (Hariyadi, 2014).

Asam lemak adalah asam monokarboksilat berantai lurus yang terdapat di alam sebagai ester di dalam molekul lemak atau trigliserida. Hasil hidrolisis trigliserida akan menghasilkan asam lemak jenuh dan tak jenuh. Asam lemak tidak jenuh memilki ikatan rangkap yang terdapat pada minyak dapat berada dalam dua bentuk yakni isomer cis dan trans. Jumlah asam lemak trans dan cis dapat mengikut di dalam makanan berlemak terutama margarin dan selai akibat dari proses pengolahan yang diterapkan seperti hidrogenasi pada saat pemanasan dengan suhu tinggi (Jansen dan Sanggam, 2002).

Nilai gizi asam lemak esensial dalam minyak dapat mencegah timbulnya atherosderosis atau penyumbatan pembuluh darah. Kegunaan minyak kedelai yang sudah 
dimumikan dapat digunakan untuk pembuatan minyak salad, minyak goreng (cooking oil) serta untuk segala keperluan pangan. Lebih dari 50\% pangan dibuat dari minyak kedelai, terutama margarin dan shortening. Hampir $90 \%$ dari produksi minyak kedelai digunakan di bidang pangan dan dalam bentuk telah dihidrogenasi karena minyak kedelai mengandung lebih kurang $85 \%$ asam lemak tidak jenuh (Bani, 2018).

Tabel 4 juga menunjukkan adanya bentuk cis pada produk cokelat batang, hal ini disebabkan karena oleogel dari minyak sawit dan minyak kedelai tidak mengalami hidrogenasi tetapi hanya dilakukan proses pengadukan untuk menyatukan dispersi minyak dan lemak kakao dengan alat pengaduk Ultra Turrax. Menurut Murry, et al., (2005), asam lemak trans dan cis merupakan golongan asam lemak tak jenuh dengan trans isomer yang mengacu pada konfigurasi ikatan rangkap karbon yang berasal dari minyak nabati yang mengalami proses pemadatan melalui teknik pemanasan atau teknik hidrogenasi parsial. Selain itu, minyak sayur (minyak kedelai, jagung, dan biji bunga matahari) mengandung sekitar $87-93 \%$ asam lemak tak jenuh yang sangat peka terhadap pemanasan yang dapat memicu terbentuknya asam lemak trans maupun cis dari suatu senyawa lemak dan minyak (Sartika, 2008).

Pengaruh asam lemak trans terhadap kesehatan dapat menimbulkan berbagai penyakit. Berdasarkan penelitian epidemiologis, trans fatty acid (TFA) atau asam lemak trans dapat menimbulkan resiko dan pengaruh negatif karena dapat menaikkan kadar LDL dalam darah, menimbulkan efek kolesterol yang tinggi, menyebabkan penyakit jantung, mengganggu metabolisme penglihatan pada mata, dan pembengkakan dinding jantung (Ovesen, et al., 1998).

Konsumsi asam lemak trans yang berlebihan sangat berbahaya bagi kesehatan. World Health Organization (WHO) dan Food and Agriculture
Organization (FAO) tahun 2010 memberikan batasan penggunaan asupan lemak trans pada makanan yaitu kurang dari $1 \%$ dari asupan energi secara keseluruhan. WHO dan FAO mendesak industri makanan untuk mengurangi jumlah asam lemak trans pada produk yang dapat mengganggu kesehatan.

\section{SIMPULAN}

Dari hasil penelitian dapat disimpulkan bahwa dari kesepuluh formulasi cokelat batang menghasilkan jenis-jenis asam lemak (fatty acid dan fat content) dengan masing-masing karakteristik kimia. Hasil penelitian menunjukkan bahwa fat content yang paling tinggi didapat di formula pasta kakao dengan oleogel minyak sawit dengan nilai $43,31 \%$, sedangkan fat content yang terendah didapat di formula bubuk kakao dari oleogel minyak sawit dengan nilai $28,80 \%$. Kandungan fatty acid total tertinggi terdapat pada formula pasta kakao dan oleogel minyak kedelai dengan kadar 93,12\%, sedangkan nilai fatty acid terendah pada pada formula bubuk kakao dan oleogel minyak kedelai dengan kadar $83,77 \%$. Analisis fisiko kimia cokelat batang menunjukkan tidak ditemukannya adanya lemak trans pada semua cokelat batang yang mana dapat disimpulkan cokelat batang ini aman bagi kesehatan.

\section{Ucapan Terima Kasih}

Ucapan terima kasih disampaikan kepada Justus E. Loppies dan Alfrida Lullung S.B yang telah membantu pelaksanaan penelitian dan selesainya karya tulis ilmiah ini. Penelitian ini dibiayai oleh DIPA Balai Besar Industri Hasil Perkebunan melalui kegiatan DIPA Tahun 2018.

\section{DAFTAR PUSTAKA}

1. Aini, N. 2011. Lebih dekat dengan cokelat. Kulinologi Indonesia III (2), Diperoleh dari www.kulinologi.biz. Diakses tanggal 13 Januari 2020.

2. Atkinson, C., Banks, M., France, C., dan 
McFadden, C. 2010. The Chocolate and Coffee Bible. London: Anness Publishing Ltd.

3. Bani, T. 2018. Minyak Kedelai, slide share.net/tubachemistry//minyak kedelai. Diakses tanggal 20 Februari 2020

4. Brown, A. C. 2010. Understanding Food: Principles and Preparation. Fourth edition. Belmont: Cengage Learning.

5. CAC, Codex Alimentarius Commision. 2003. Codex for Chocolate and Chocolate Products.

6. Elisabeth, Dyan, Suharyanto dan Rubiyo, 2008. Pengaruh Fermentasi Biji Kakao terhadap Mutu Produk Olahan Setengah Jadi Cokelat. Jurnal Balai Pengkajian Teknologi Pertanian Bali. Bali.

7. Food and Drug Administration (FDA). 2015. Foodborne IIInesses: What You Need to Know.

8. Hariyadi, P. 2014. Mengenal Sawit dengan Beberapa Karakter. GAPKI. Wordpress: Jakarta.

9. Jansen, S. dan Sanggam D. R. T. 2002. Asam Lemak Trans Dalam Makanan dan Pengaruhnya Terhadap Kesehatan, Jurnal Teknologi dan Industri Pangan. Vol XIII, No. 2, 184-188.

10. Lipp E.M., and Anklam, E. 1998. Review of Cocoa Butter and Alternative Fats for Use in Chocolate - Part A. Compositional Data Food Chemistry, 62(1). 73-97.

11. Noordiansyah. 2016. Peningkatan Karakteristik Olahan Cokelat yang Dipengaruhi Penambahan Cocoa Butter Substitute dan Tepung Kacang Koro (Canavalia Ensiformi L). Program Studi Teknologi Pangan, Fakultas Teknik, Universitas Pasundan Bandung.

12. Murry, R.K., Granner, Mayer, P., dan Rodwell, V.W. 2005. Biosintesis Asam Lemak. Editors. Biokimia. Jakarta.
13. Ovesen L., Leth T and Hansen K. 1998. Fatty acid composition and contents of trans monounsaturated fatty acids in frying fats, and in margarines and shortenings marketed in Denmark. J Am Oil Chem Soc. 75(9): 1079-1083.

14. Patel, A.R., \& Dewettinek, K. 2015. Comparative Evaluation of Structured Oil Systems; Shellac oleogel, HPMC Oleogel, and HIPE gel. European journal of Lipid Science and Technology.

15. Ramlah, S. 2016. Karakteristik Mutu dan Citarasa Cokelat Kaya Polifenol. Jurnal Industri Hasil Perkebunan.Vol.10. BBIHP. Makassar.

16. Ristanti, E.Y. Ramlah, Daming, W. 2017. Laporan Hasil Litbang Pembuatan Oleogel. BBIHP Makassar.

17. Ristanti, E.Y. Ramlah, Asriati, D.W, Amalia, A.N. 2018. Laporan Hasil Litbang Aplikasi Oleogel pada Pembuatan Cokelat Batang. BBIHP. Makassar.

18. Samudhita, L, Dassanayake, K., Kodali, D.R., and Ueno, S. 2011. Current Opinion in Colloid and Interface Science, 16 (5), 432-439.

19. Sartika, Ratu Ayu Dewi. 2008. Pengaruh Asam Lemak Jenuh Tidak Jenuh dan Asam Lemak Trans Terhadap Kesehatan. Jurnal Kesehatan Masyarakat Nasional, Vol.2, No.4, p.154-160.

20. Sokopitojo, S. 2008. Aplikasi CBE dalam Industri Snack Berbasis Cokelat. Food Review Indonesia. Malang: Universitas Negeri Malang.

21. WHO dan FAO. 2010. World Health Organization and Food Agriculture Organization. Fats and Fatty Acids in Human Nutrition Report and Expert Consultation in Food and Nutrition Paper. Vol 91. Food and Agriculture Organization at the United Nation. 